\title{
THE MOTIVATION OF BETRAYAL BY LEAKING OF CLASSIFIED INFORMATION
}

\author{
Laurențiu-Leonard LĂZĂROIU \\ "Nicolae Bălcescu" Land Forces Academy, Sibiu, Romania \\ 1llazaroiu@yahoo.com
}

\begin{abstract}
Trying to forecast the human behavior involves acts and knowledge of motivational theories, applicable to profile of each organization and in particular to each individual's style. The anticipation of personal attitudes has not the only aim for a passive monitoring of professional activity, but also wants to increase performance of risk avoidance, in acordance with a specific organizational environment. The emergence and development of motivational forms and values, whose projections determine social crimes, are risk factors, affecting the professional activity of the person, but also affecting the performance and stability of the institution. Moreover, if the motivation determines attitudes aimed at compromising classified information, the resulting actions may be considered as threats to national security. The prevention of such threats can only be achieved by understanding motivational mechanisms and external conditions for the perssonel that make it possible to transform some intentions into real actions.
\end{abstract}

KEYWORDS: motivation, behavioral attitudes, classified information, compromise the security

\section{Introduction}

What psychologists call Ego (S. Freud), I (K. Lewin), Proprium (G. Allport) or Self-consciousness, all of these are as many ways to express in different queries self-assessment of a human subject's attitudes and actions of each of us.

In his view, for P. Popescu-Neveanu (2013), motivation, as a behavior's trigger, builds between stimulus and response or reaction a system of filters and comparators that allow information to propagate selectively, depending on the significance of the assembly lines for each person. Motivation, by its reflector nature, represents a link between individual and social environment and it keeps the human being outside the scope of determinism. At the same time, the motivation has a causal effect transformed and sedimented inside the person and makes a break in the chain of external causes (Popescu-Neveanu, 2013, p. 706). We believe that the relationship between the two operations causes the behavioral initial reaction (which can acquire an unusual scale, a negligible expression or even it can be absent), followed by an assumed behavior.

2. Motivational Aspects Specific to People who Have Access to Classified Information

Aspects about the motivation's values, interpreted as the dominant command center of the individual behavior, are often realized only in two separate cases of professional activity, specific to research 
of human personality of subjects which have access to classified information (based on functions that are performed by each member in certain organization):

a) during the selection and training of individual's skills in order to a proper performance with classified information. For example, professional trainers interested to determine staff engaged in training forms to achieve a legal behaviors conform to the rules of the organization;

b) if it is intentionally committed some security incidents, detrimental to the protection of classified information. For example, the interest on certain values of motivation, in a process in witch members of an incident research team attempt to document the event and to explain the factors that led to a faulty action.

Starting from the idea of professional performance, caused in a certain way by the institutional restrictions, we could expand and develop the issue of motivation values generated by human action, trying to answer the following questions (often considered as been rhetorical):

- If human beings share the same needs, why their behaviors that bring them satisfaction are so different?

- Why the same person and between different individuals some activities are fulfilled with interest, while other activities are marked by indifference?

- Why some individuals see in the challenges were offered the opportunity for professional development, while others with the same lineup and similar professional experiences, avoid or reject these challenges?

- What is the type and amount of motivation that makes the individual to break the institution's rules (institution to which he belongs), in this case, what is the motivation of betrayal by transmitting classified information?

In the concept of procesual-organic theory "the human beings are products and expressions of some information-energy processes of biological and social, their specificity is given by interpretative process, exceeding bioprocessing information and their specificity achieves awareness. More than that, the human being is shaped from birth, throughout ontogeny by playing the frame belonging to socio-organization in which he is socialized". The individual, through action and his life experience, as the internalisation of specific human condition, produces both a view obout the world and an image of oneself, the self-image (Radu, 1997, pp. 394-395). Therefore, in the context of the topic, knowing how the subject is and organize his mental world and also how he perceives himself, his own self-evaluation in different situations, all of these represent an important step to for understanding a specific human behavior.

Focus on the top level of needs from the Maslow's pyramid of needs, in our endeavor to establish a relationship between motivation and behavior, we believe that the theory of "acquisition success", developed by D. McClelland, present a great value of interest. According to McClelland, individual behavior will be determined by one of these three categories of needs: affiliation, power and achievement. Therefore McClelland grouped the staff of an organization into three types: people characterized by the need for affiliation, people characterized by the need for power, people characterized by the need for achievement (Manolache, 2007, pp. 103-108).

According to I. Radu (1997), essential trend to human is the "need to control the world" and only apparently, human being is guided by other values like: power, fame, money (according to G. W. Hege); desire for power (F. Nietzsche, A. Schopenhauer); fortunately, praise and success (Aeschylus). The listed values, real or illusory, are confirmations of a subjective "control the world" perception and their opposites is the expression of loss or 
abandonment of control possibilities. For G. Allport, personality is something that comes from inside the individual minimizing the importance of the others, of social contacts and environment's role in shaping the personality. In his view, the motivation of the adult is acting according the principle of increasing psychological tension in order to achieve his objectives, contrary to the psychological tension reduction to achieve the objectives (Aniței, 2016, pp. 45-76). Thus, taking into account Allport's idea, it concludes that the power of motivation is maintained by the "fire" of a psychological tension. In our analysis, in which we propose to determine the negative motivation, that leads to violation of professional rules, Allport's principle brings into atention that moment when the internal tension increases "criminal" motivation, at a higher level and reaches its peak.

What will happen then? Will the human subject recognize the bad intentions and will not take actions contrary to the interests of the organization or overcoming the fear of punishment, he will continue the criminal acts, even if less motivated (to carry out those criminal actions)?

\section{Motivation for Taking Criminal} Acts

From the perspective of a defensive view on intelligence, often specific to counterintelligence work, if performance achievement and the positive results of professional activity is the organizational aim, then should be analyzed the professional failures and should be archived the experience, as learned lessons. Thus, to understand some specific motivational aspects, we used the statistical relevant values to different historical periods. The research conducted by the research center of the US, Defense Personnel Security Research Center (PERSEREC), on a number of 117 cases of leaking classified information, with higher value to the the
United States national security, revealed some issues of concern about the motivation that was the basis of these threats (Herbig, 2008).

On the 117 cases that studied 117 people, aged at least 25 years for the military perssonel and 33 years old for civilians, the motivation of committing betrayal act was ranked as follows:

a) financial motivation generated by material necessities - 52 cases;

b) ideological motivation, the sympathy for an ideology - 18 cases;

c) desire for revenge due to conflicts at work - 15 cases;

d) non-acceptance of the political regime - 9 cases;

e) coercion to provide information, blackmail - 4 cases;

f) for adventure -3 cases.

On the other side, the offensive action to collect information through secret or less secret human sources will be directed to identify individual motivation, capable of influencing new attitudes of acceptance of collaboration for operational tasks that have to be performed in a secret manner.

Researchers have established that the motivation for the actions that lead to betrayal by sending in illegal way sensitive information has historical value, determined by conditions and social relations in certain periods of time. The results revealed that in the $40 \mathrm{~s}$, from 12 cases of treason acts identified in the United States, 9 of them were motivated by ideological concepts. The priority for this motivation was not repeated later in history, in the favor of financial incentives. By analyzing this aspect, we consider that the motivation for a certain action, interpreted in acordance with organizational rules as been positive or negative, depends on the historical context. Thus, human behaviors is sensitive to social values that are specific to a particular temporal landmark, not only influenced by the organizational profile. 
According to M. Boza (2010, pp. 165-169), with her theory of reasoned action, the performance of individual behavior is primarily determined by the person's intention to perform that behavior and that intention is dependent on two important factors: the attitude of human subject towards that behavior (beliefs about the outcome conduct and interpretation of value for himself) and the influence of the social environment to the person or some subjectives values (like beliefs about what others will think about this behavior).

Currently, the ideological motivation for changing attitudes and behavior is found in specific recruitment procesures to improve the atraction for new members, managed by terrorist organizations, handling individual believes in order to reach the idea of self sacrifice to fulfill the organization's objectives. For human subject the higher values of motivation are achieved in timet, while criminal proceedings are aware (of manipulation effect), his own believes and attitudes are changed in time by promoting radical philosophy, finally new concepts about life will be gradually achieved.

In each human activity, when the call to motivation is used to change a human behavior, the yield can be achieved, if all the conditions contained in the integrative theory of motivation built by Porter and Lawler are fulfilled. These conditions are designed after these human values:

a) the value of rewards;

b) the perception of effort needed or the probability of reward (instrumentality);

c) effort (representing expectations);

d) the ability to perform a task;

e) the perception of the task;

f) yield;

g) reward;

h) reward perceived as fair;

i) satisfaction.
According to this model, the motivational process complying sequence given in presented sequence. Thus the individual has his own perceptions on: hopes, actions, valence and instrumentality. Only when the human being sees and analizes in a realistic way the task, according with his skills and perceptions, he as action's subject correctly interprets the risk and achieves the level of performance in order to receive an appropriate reward. Clearly, the skills and techniques of persuasion for the agent who plans to recruit a person for acts contrary to principles of social are very important. $\mathrm{He}$, seen as a member of a terrorist organization or even a member of foreign intelligence structure, will present in a proper manner the new conditions of the theory of integrative motivation. The aim is easy to find, it represents a lot of personal assets used to build trust and to mitigate the subjective assessment of risk by targeted agent.

\section{Conclusion}

Scientific theories on personality, related with individual's own motivational interpretations have several objectives such as: the description of human behavior, by appealing to various taxonomies; explaining that behavior by using information on the influences of various types (from the social environment to heredity). The main aim for each social theory is to predict individual's behavior in general, but also in some typical situations. The research of taken risk, assumes that human freedom is conditional by the characteristics and strength of the community, under the values of human entity to which the individual belongs and also bythe environments, mixture (social, intellectual, institutional, informational) and the interference in which he lives is fluid, unpredictable, sometimes contradictory and turns every moment. We can find both facilities or liberties and many constraints. 


\section{REFERENCES}

Aniței, M., (coord.). (2016). Tratat de psihologia personalitățiii. București: Trei.

Boza, M. (2010). Atitudinile sociale și schimbarea lor. București: Universitatea Națională de Apărare.

Herbig, K. (2008). Changes in espionage by Americans 1947-2007, Monterey, CA, Defense Personnel Security Research Center, available at: https://www.fas.org/sgp/library/ changes.pdf

Manolache, I. (2007). Psihologia în mediul militar. București: Universitatea Națională de Apărare.

Popescu-Neveanu, P. (2013). Tratat de psihologie generală. București: Trei.

Radu, I. (1997). Imaginea de sine și comportamentul militarilor în situații limită, Teză de doctorat. București: Universitatea Națională de Apărare. 